Archived version from NCDOCKS Institutional Repository http://libres.uncg.edu/ir/asu/

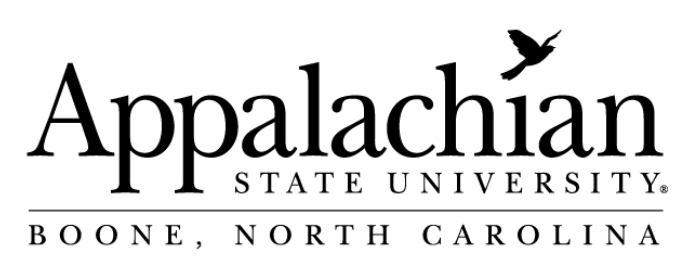

\title{
How Unions Affect Shareholder Wealth In Firms Announcing Layoffs
}

By: Richard W. Pouder, Hugh D. Hindman, and R. Stephen Cantrell

\begin{abstract}
We investigate whether investor anticipation of future performance differs between union and nonunion firms following corporate layoff announcements. Using event-study methodology and multivariate regression analysis, we find that the stock market reaction to layoff announcements is negatively related to nonunion firms and positively related to union firms.
\end{abstract}

Pouder, R.W., Hindman, H.D. \& Cantrell, R.S. J Labor Res (2004) 25: 495. https://doi.org/10.1007/ s12122-004-1027-4. Publisher version of record available at: https://link.springer.com/article/10.1007/ s12122-004-1027-4 


\title{
How Unions Affect Shareholder Wealth in Firms Announcing Layoffs
}

\author{
RICHARD W. POUDER and HUGH D. HINDMAN \\ Appalachian State University, Boone, NC 28608 \\ R. STEPHEN CANTRELL \\ Clemson University, Clemson, SC 29634
}

We investigate whether investor anticipation of future performance differs between union and nonunion firms following corporate layoff announcements. Using eventstudy methodology and multivariate regression analysis, we find that the stock market reaction to layoff announcements is negatively related to nonunion firms and positively related to union firms.

\section{Introduction}

Several recent studies in the strategic management literature have investigated the relationship between layoff announcements and shareholder wealth and have shown that certain characteristics of the announced layoff act as signals which guide investors' reactions to the announcement (Lee, 1997; Urse) and Armstrong-Stassen, 1995; Wor- rell et al., 1991). Another research stream in the industrial relations literature has inves- tigated the influence of union-related announcements on shareholder wealth, including strikes (Becker and Olson. 1989), u nion organizing (Ruback and Zimmerman, 1984), union decertification (Pearce et al., 1995), bargaining (Abowd, 1989), concession bar- gaining (Becker, 1987), and introduction of profit-sharing plans (Florkowski and Shas- tri, 1992). This research generally supports the idea that u nion-related annou ncements affect shareholder wealth.

Taken together, these two research streams suggest the possibility that investors' reactions to layoff announcements may be conditioned by the firm's union status. To date, no published study in either the strategic management literature or industrial relations literature has examined this topic. This study determines whether investors' reactions to layoff announcements differ between union and nonunion firms. We conduct our investigation using event-study methodology and multivariate analysis in a sample of union and nonunion firms making layoff announcements over the period 1989-1996.

\section{Background}

Layoff Announcements and Shareholder Wealth. Over the past two decades, nearly all Fortune 1000 firms have had at least one permanent layoff of employees. The growth 
of layoffs in U.S. corporations during this time has sparked much research on how layoffs affect shareholder wealth. Worrell et al. (1991) used an event-study methodology to show an overall significant, negative investor reaction to layoff announcements. Similar reactions have been observed in Canadian (Ursel and Armstrong-Stassen, 1995) and Japanese corporations (Lee, 1997), suggesting that a layoff announcement often confirms or signals to investors a firm's financial problems (Worrell et al., 1991).

Although layoff announcements decrease shareholder wealth in the aggregate, investors' reactions will likely vary according to information they seek and obtain on characteristics of both the announcement and the firm. For example, investors tend to react more negatively to layoffs at firms with poor financial performance prior to the announcement (Urse! and Armstrong-Stassen, 1995; Worrell et al., 1991). Furthermore, proactive layoff announcements -those citing attempts to improve firm efficiency or profitability -have a smaller negative impact on shareholder wealth than reactive layoff announcements -those citing declining demand or financial distress as motivating the layoff (Lee, 1997; Worrell et al., 1991). Research has also shown a negative relationship between shareholder wealth and the percentage of workers that a firm intends to lay off (Lee, 1997; Worrell et al., 1991). In addition, investors react more negatively when a firm makes a single layoff announcement than when it makes multiple announcements (Lee, 1997).

Unions and Shareholder Wealth. Unions, on behalf of their members, are viewed as competing with shareholders for corporate wealth. As a rule, the greater the level of unionization, the lower the profitability of the firm as measured by returns to shareholders (Becker and Olson, 1989; Hirsch, 1991). So shareholders may perceive that their interests would be better served in nonunion, or less unionized, firms.

It is not simply a matter of labor costs, however. Certainly unions elevate the costs of wages and benefits, but offsetting productivity gains, where they are achieved, may neutralize the impact on labor costs (Belman, 1992). Still, the perception that unions elevate labor costs continues to be a powerful impetus for management opposition to unionization (Rose and Chaison, 1996). Unions may not extract monopoly profits, that is, claim larger shares in highly concentrated industries. Instead, unions compete for expenditures in discretionary areas such as research and development (Hirsch and Connolly, 1987) and capital investment (Voos and Mishel, 1986). What is seen as good for the union and its members is generally viewed as detracting from shareholder wealth.

Shareholders do not need to rely exclusively on management to secure their interests vis-a-vis unions. Shareholders can also condition their investment decisions on various union activities and events. The event-methodology studies cited previously indicate that investors react negatively to union gains. They react negatively to union organizing efforts, and even more so when those organizing efforts are successful (Ruback and Zimmerman, 1984), but they react positively when unions are decertified (Pearce et al., 1995). They react negatively to strikes, depending on their duration and intensity (Becker and Olson, 1986), and negatively to union wage gains (Abowd, 1989), 
but positively to concessionary agreements (Becker, 1987) and to the introduction of profit-sharing plans (Florkowski and Shastri, 1992).

Unions, Layoffs, and Shareholder Wealth. If investors generally react negatively to layoff announcements, should they be expected to react any differently when those announcements are issued by more heavily unionized firms? In either case, the layoff announcement sends negative signals. If investors interpret the announcement as conveying information about the firm only, we should expect the null hypothesis -that there are no significant differences in shareholder wealth between union and nonunion firms. If,alternatively, investors interpret layoff announcements in union firms to imply a weakening of the union's position, their negative stock-market reaction may be tempered somewhat by this more favorable information, so the stock market reaction might be less negative or even positive in union firms. Or there might simply be less shareholder reaction to announcements in union firms. Either way, the alternative hypothesis suggests a less unfavorable or favorable shareholder reaction to layoffs in more unionized firms.

\section{Methods and Data}

Event Study. Following the event-study methodology presented in detail in Brown and Warner (1985), we estimate a market model for each firm and then derive estimates of abnormal returns in union and nonunion firms. Assuming an announcement date of $t=0$, we estimate market model parameters for each firm over a one-year (240trading-day) period from day $t=-331$ to day $t=-91$. We then calculate abnormal returns as deviations from returns expected if there were no announcement, as estimated by the market model. Abnormal returns for each firm are standardized by their standard deviations to derive standardized abnormal returns and summed for all firms to compute a measure of the cumulative abnormal returns over the number of days comprising the event window. Daily stock return data come from the Center for Research in Security Prices (CRSP) equally weighted market index for announcements for firms listed on the New York Stock Exchange, American Stock Exchange, and NASDAQ.

Sample Construction. We obtained our sample by searching the Wall Street Index for layoff announcements over the years 1989-1996. Our sample is limited to firms in the manufacturing and transportation/utility industries because firms in these industries have a higher proportion of union membership than firms in other industries. We included only permanent layoff announcements because an insignificant number of the announcements involved temporary layoffs. Including only permanent layoff announcements in the sample is not problematic, since previous research has shown that temporary layoffs have significantly less impact on investors' anticipation of the future financial performance of the firm (Lee, 1997; Worrell et al., 1991). We deleted announcements if a merger or acquisition, stock split, change in dividend policy, or top management change was reported for the firm during the three days before and the one day following the layoff announcement. As McWilliams and Siegel (1997, p. 634) report, eliminating the effect of contaminating events such as these "is perhaps the most 
critical assumption of the [event-study] methodology." Using these sampling criteria, our initial sample consisted of 233 unique announcements for 132 firms.

A weakness in our data set is that only seven of the 121 announcements for union firms conveyed information that clearly indicated whether union workers would be affected by the layoff. This pattern is consistent with the fact that layoff announcements rarely convey information on occupational characteristics or labor-management disputes (Ursel and Armstrong-Stassen, 1995). Although industry analysts and, hence, their investor clients are likely to know the union status of workers targeted for layoffs, our analysis is limited solely to union status at the level of firms rather than individual employees. For a firm's union status, we used the Bureau of Labor Statistics publication, Companies (National) With Unions (as o 913196). This source, which consists of companies having collective bargaining agreements that cover 1,000 or more workers, provided information on the number of workers affected, as well as the effective and expiration dates of collective bargaining agreements. For the 1989-1996 study period we found that 24.4 percent of the transportation, communications, and public utility firms and 22.9 percent of the manufacturing firms were unionized.

Regression Analysis. We estimated a multivariate regression to test the joint influence of characteristics of the layoff announcement on shareholder wealth. The crosssectional variation in cumulative abnormal returns is regressed on union status and other previously discussed announcement characteristics. As a measure of union status, we calculated the proportion of union workers in a firm for each announcement as a measure of un ion status. For a firm's pre-announcement performance, we used data obtained in the Compustat Data Tapes to compute the percentage change in industry-adjusted profit margin for the two years prior to the announcement year. To account for investors' assessment of layoff announcements as reactive or proactive, we read and coded each announcement ( 0 = reactive layoff; 1 = proactive layoff). We also included the percentage of the firm's work force targeted in the layoff. While some announcements provided a percentage, others gave only a total number. To calculate a percentage, we divided number of layoffs by total employment as reported in the previous quarter in the Compustat Data Tapes. In addition, we accounted for possible differences in the information conveyed in single versus multiple announcements made by the same firm. We searched the Wall Street Journal Index for a three-year period prior to the current announcement to find multiple layoff announcements (coded as 0 = single announcement; 1 = multiple announcements). Finally, we included total firm employment to control for size effects, since larger firms tend to lay off greater proportions of union workers than their smaller counterparts (Groothuis, 1994).

\section{Research Findings}

We found no statistically significant differences between mean abnormal returns for firms in each industry category and therefore report findings for combined industries. Table 1 presents the cumulative abnormal returns and Z-statistics over an event window that includes the announcement date, the day preceding the announcement date, 
Table 1

Cumulative Abnormal Returns and (Z-Statistics) for Days - I to 1

\begin{tabular}{|c|c|c|}
\hline $\begin{array}{l}\text { All Firms } \\
(\mathrm{N}==233)\end{array}$ & $\begin{array}{l}\text { Union Firms } \\
(\mathrm{N}=121)\end{array}$ & $\begin{array}{l}\text { Nonunion Firms } \\
\left(\mathrm{N}=1 \begin{array}{ll}1 & 2\end{array}\right)\end{array}$ \\
\hline $\begin{array}{l}-0.0045 \\
(-1.37)\end{array}$ & $\begin{array}{l}0.0014 \\
(0.76)\end{array}$ & $\begin{array}{l}-0.0109^{* *} \\
(-2.77)\end{array}$ \\
\hline
\end{tabular}

Note: $\bullet(* *, * * *)$ indicate significance at the .JO $(.01, .001)$ level, twotailed test.

and the day following the announcement date. This three-day event window is frequently used in event studies and assumes that the effects of events are quickly incorporated into firms' stock prices in efficient capital markets (McWilliams and Siegel, 1997). For all firms in the sample, there is a negative market reaction to layoff announcements. Although not statistically significant, the overall negative reaction concurs with previous research findings. Table 1 also shows a negative and statistically significant cumulative return for nonunion firms and a positive, though not significant, cumulative return for union firms. Thus, the union status of a firm might help investors interpret the impact of a layoff on firm value. Moreover, we found a statistically significant difference between mean cumulative abnormal returns in union and nonunion firms $(\mathrm{t}==1.98 ; p<.05)$.

Table 2 presents the results of the regression analysis that tests how union status and other layoff characteristics jointly influence cumulative abnormal returns over the same three-day window used in the univariate test. The results of this more robust test of union status show that the coefficient on the percentage of union workers is positive and significant, thus supporting the inferences from the univariate test. The results are also consistent with previous studies. In support of findings by Lee (1997), we show that proactive announcements are a significant positive predictor of abnormal returns. Furthermore, a firm's recent financial performance provides an important signal to investors about future prospects (Ursel and Armstrong-Stassen, 1995; Worrell et al., 1991), as evidenced in the positive and significant coefficient on pre-announcement earnings.

\section{Conclusion}

On the surface, a firm's union status matters in how the stock market reacts to layoff announcements, and the presence of a union reverses the expected negative reaction. But what explains these positive (or at least nonnegative) returns to layoff announcements in more unionized firms? To the extent that union members were more likely to be laid off, our findings are generally consistent with previous research that union- 
Table 2

Results of Regression Analysis

(standard errors in parentheses, $N=200$ )

$\begin{array}{lc} & -0.014 \\ \text { Intercept } & (0.012) \\ & \\ \text { Percentage Unionized } & 0.014^{* *} \\ & (0.007) \\ \text { Percentage Layoff } & -0.001 \\ & (0.001) \\ \text { Firm Size } & 0.001 \\ & (0.001) \\ \text { Reason for Layoff } & 0.008^{* *} \\ & (0.004) \\ \text { Prior Layoff } & -0.001 \\ & (0.004) \\ \text { Profit Marginb } & 0.001 * * \\ & (0.000) \\ \text { F-statistic } & 3.03^{* * *} \\ \text { R2 (\%) } & 8.6\end{array}$

Notes: $*(* *, * * *)$ indicate significance at the . I $0(.05, .0 \mathrm{I})$ level using two-tailed test. 'Natural $\log$ of variable. bRatio of income before extraordinary items to total sales.

related events that signal a weakening of the position of the union produce positive investor reactions. Unfortunately, our inability to determine the union status of laidoff workers is a major limitation. Future research that can more accurately ascertain the union status of workers affected by layoffs should address this gap. Until then, there is no reason to assume, ceteris paribus, that layoffs disproportionately affect a firm's union members, however much unionized the firm. Whether union members were more likely to be laid off because they were more expensive to keep or whether union members were less likely to be laid off because they were more expensive to let go is a key empirical question that we did not address.

Iflayoff announcements in unionized firms do not signal the layoff of union members, it is less clear how the absence of a negative stock market reaction should be explained. It appears that investors treat these layoff announcements much like they treat proactive layoff announcements. One explanation that is consistent with our findings, yet seems improbable, is that investors recognize the recuperative value of unions to firms in trouble. That is, a firm facing layoffs may be a firm in trouble, but one 
with a union may be seen as having an ally with clear interests in assuring the longrun viability of the firm in order to protect the remaining jobs.

In sum, further research is needed in order to fully explain our findings. Perhaps event methodologies could be coupled with interview or survey research that more directly taps the perceptions of investors and senior executives. Another intriguing research question is how the stock market would react to announcements of hiring union versus nonunion workers. Hiring announcements would generally send strong positive signals to the market. In line with our findings, however, would the hiring of union workers be associated with a negative market reaction?

\section{REFERENCES}

Abowd, John M. "The Effect of Wage Bargains on the Stock Market Value of the Firm." American Economic Review 79 (September 1989): 774-800.

Becker, Brian E. "Concession Bargai ning: The Impact of Shareholders Equity." Industrial and Labor Relations Review 40 (January 1987): 268-79.

and Craig A. Olson. "Unionization and Shareholder Interests." Industrial and Labor Relations Review 42 (January 1989): 246-61.

Belman, Dale. "Unions, the Quality of Labor Relations, and Firm Performance." In Lawrence Mishel and Paula B. Voos, eds. Labor and Economic Competitiveness. Armonk, N.Y.: M.E. Sharpe, 1992, pp. 41108.

Brown, Stephen J. and Jerold B. Warner. "Using Daily Stock Returns: The Case of Event Studies." Journal of Financial Economics 14 (March 1985): 3-31.

Davidson, Wallace N., Dan E. Worrell, and Louis T. W. Cheng. "The Effectiveness of OSHA Penalties: A Stock-Market-Based Test." Industrial Relations 33 (July 1994): 283-96.

Florkowski, Gary W. and Kuldeep Shastri. "Stock-Price Response in Unionized Settings." Journal of Labor Research 13 (Fall 1992): 407-20.

Groothuis, Peter A. "Turnover: The Implication of Establishment Size and Unionization." Quarterly Journal of Business and Economics 33 (Spring 1994): 41-53.

Hirsch, Barry T. "Union Coverage and Profitability among U.S. Firms." Review of Economics and Statistics 73 (February 1991): 69-77.

and Robert A. Connolly. "Do Unions Capture Monopoly Profits?" Industrial and Labor Relations Review 41 (October 1987): 118-36.

Lee, Peggy M. "AComparative Analysis of Layoff Announcements and Stock Price Reactions in the United States and Japan." Strategic Management Journal 18 (December 1997): 879-94.

McWilliams, Abagail and Donald Siegel. "Event Studies in Management Research: Theoretical and Empirical Issues." Academy of Management Journal 40 (June 1997): 626-57.

Pearce, Thomas G., James E. Groff, and John R. Wingender. "Union Decertification's Impact on Shareholder Wealth." Industrial Relations 34 (January 1995): 58-72.

Rose, Joseph B. and Gary N. Chaison. "Linking Union Density and Union Effectiveness." Industrial Relations 35 (January 1996): 78-105. 
Ruback, Richard and Martin B. Zimmerman. "Unionization and Profitability: Evidence from the Capital Market." Journal of Political Economy 92 (December 1994): 1134-57.

Urse], Nancy and Marjorie Armstrong-Stassen. "The Impact of Layoff Announcements on Shareholders." Relations Industrielles 50 (Summer 1995): 636-49.

Voos, Paula B. and Lawrence R. Mishel. "The Union Impact on Profits: Evidence from Industry Price-Cost Margin Data." Journal of Labor Economics 4 (January i986): I05-33.

Worrell Dan E., Wallace N. Davidson, and Varinder M. Sharma, "Layoff Announcements and Stockholder Wealth." Academy of Management Journal 34 (September 1991): 662-78. 